\title{
Waste Dispo: An Enhanced Approach for Waste Disposal
}

\author{
Anvesh Dhumal ${ }^{1}$, Varghese Daison ${ }^{2}$, Aadesh Dalvi ${ }^{3}$, Er. Chandan Prasad \\ BCA Scholar, MACT, School of Information \& Technology, Pune, India ${ }^{1,2}$ \\ BCA Scholar, CTIS, School of Information \& Technology, Pune, India ${ }^{3}$
}

Assistant Professor, IT, Ajeenkya DY Patil University, Pune, India ${ }^{4}$

\begin{abstract}
Issues related to waste management in the context of Indian Cities still requires a path finder as most of the citizens need to be addressed in the primary stage. Municipal solid waste management is a major environmental problem in India. Due to quick increase in development, industrialization and population, the generation rate of municipal solid waste in Indian cities and towns is also increased. Negligence of municipal solid waste can cause adverse environmental impacts, public health risk and other socio-economic problem. This paper presents an overview of the existing systems of solid waste management in India which need an immense improvement; the proposed system will help the competent authorities responsible for municipal solid waste management. The present paper sorts the certain issues related to Waste management which have been experienced while being involved in various cities in national arena and picks up certain unaddressed issues related to Waste management in Indian Cities. The main aim of this paper is to reduce the amount of waste in public areas while giving the citizens an opportunity to volunteer in the waste management Process and with a learned group of participants try to evolve an effective pathway for its management.
\end{abstract}

Keywords: Municipal Solid Waste, Characteristic, Management, India, Disposal, Waste Management, Citizen Volunteers, Unaddressed Issues.

\section{INTRODUCTION}

Waste management in India has become a foremost concern as the number of waste disposed in public grows day by day. India is the second most populated country in the world and hence produces a large amount of waste every day. This project helps the public by sorting the waste efficiently and in a more organized way by providing convenient waste disposal location information through a Technology based platform with a user-friendly Interface. In this growing era of modern technologies where smartphones and the internet is used by majority of people, we have decided to use these assets as a tool to help reduce waste.

\section{Why is Waste a Problem?}

As already mentioned, waste disposal in India simply involves rounding up the waste from different parts of the city, and dumping everything in a landfill. Once a landfill is completely occupied, a new landfill is discovered in a different part of the city. The Energy Research Institute estimates that $1400 \mathrm{sq}$. $\mathrm{km}$. of land would be required by 2047 for municipal waste!

Cities those are fortunate enough to have a river passing through them, have an additional dump for all their garbage. The state of the Yamuna River in Delhi is a testimony to this fact. The river practically doesn't flow at all. Expansive white deposits can be seen on their surfaces that prevent the flow. The deposits are nothing but toxic wastes that have reacted with the water. Practically no living creature lives in this section of the river. The landfill method is simply one that creates land pollution (and in some cases, ground water contamination). The waste is not subjected to recycling, composting, or any other form of environmental treatment. Hazardous toxic wastes lie side by side with the organic wastes in the landfill.

The waste disposal issue has been given a small budget by the Government. Limited by this, the municipalities are illequipped to deal with the massive amounts of waste they collect every day. Another problem is their inefficiency in collecting the waste. Currently, their efficiency is only about 50 to 80 per cent. The common man living in a populated urban city can tell you that the garbage boy seems to take holidays every now and then. The real problem is that he has collected so much that he can't store any more trash in his truck for the day, which is why he seems to take a "holiday" and does not come to your house. On the one hand, we can blame the municipality for not having enough resources to collect all the garbage. On the other hand, we ourselves are to blame for generating such huge amounts of garbage.

\section{LITERATURE SURVEY}

Indians generate 14 million tons garbage daily. Of the total municipal solid waste generated in India daily, only $83 \%$ 


\section{ISO 3297:2007 Certified}

Vol. 5, Issue 3, March 2017

of it is collected and only the $29 \%$ of what is collected is treated [1]. In the capital of our country, i.e. Delhi, there are only 2500 community bins that serve as secondary collection centre before being disposed of at landfills. Therefore a lot of waste produced in Delhi goes to the streets and public corners. This is a state not only in Delhi but all over India [2].

In Kolkata there are only two landfill sites for dumping wastes namely Dhapa and Garden Reach. Both are nearly saturated. Kolkata produces 4000 tons of garbage per day and it is day by day becoming a growing problem for dumping of waste [2]

Mumbai, a growing metropolis, has the biggest problem of waste disposal out of all cities. "Though there are rules that say residents must segregate waste, the BMC (Bombay Municipal Corporation) has no treatment centres and eventually dumps it all in one place, so people no longer bother" [2].

According to the Associated Chambers of Commerce and Industry (ASSOCHAM) predictions, "India will generate 130 million tons of waste by 2018 from the current 93.5 million tons in 2016. And by 2020, India will generate 5.2 trillion tons of waste" [3].

As per rule 4 of the Municipal Solid Waste (Management and Handling) says that the year 2000 onwards every municipal authority is responsible for infrastructure development for segregation and processing of all the municipal solid waste, commonly known as garbage.

However, the implementation is very weak. In Mumbai, only $10 \%$ of the Municipal Solid Waste is treated in bioreactors. In Delhi $50 \%$ is treated. Of the 1.4 lakh tons of Municipal Solid Waste generated in our country per day, only $24 \%$ is treated. Compared that to Sweden, where less than $1 \%$ of the Municipal Solid Waste generated by homes goes to the landfill and balance $99 \%$ is either converted to power or is recycled or composted.9 billion tons of litter ends up in the ocean every year [4]. Marine life suffers greatly due to incompetence of waste disposal.

Per capita waste generation in foremost Indian cities varies from $0.2 \mathrm{Kg}$ to $0.6 \mathrm{Kg}$ [5].Difference in per capita waste generation between lower \& higher income groups vary between 180 to $800 \mathrm{gm}$ per day.

The urban local bodies employ around Rs.500 to Rs.1500 per ton on solid waste for collection, transportation, treatment and disposal. About $60-70 \%$ of this sum is spent on collection, $20-30 \%$ on transportation and below $5 \%$ on final disposal.

Calorific value of Indian solid waste is ranged around 600 and $800 \mathrm{Kcal} / \mathrm{Kg}$ and the density of waste is ranged around 330 and $560 \mathrm{Kg} / \mathrm{m} 3$ [6].Waste collection competence in Indian cities ranges from $50 \%$ to $90 \%$.
Out of the entire municipal waste acquired, on an average $94 \%$ is dumped on land and 5\% is composted [7] Between 2000 and 2025 the waste composition of Indian garbage will experience the following changes:

- Organic Waste will increase from $40 \%$ to $60 \%$

- Plastic will increase from $4 \%$ to $6 \%$

- Metal will rise from $1 \%$ to $4 \%$.

- Glass will rise from $2 \%$ to $3 \%$.

- Paper will rise from 5\% to $15 \%$.

- Others (ash, sand, grit) will fall from $47 \%$ to $12 \%$ [8].

\section{PROPOSED SYSTEM}

The proposed system uses WEB/Mobile application which has to be implemented by the corporation/ municipality/government which allocates waste disposal locations and services to the public. The application also allows citizens to volunteer to take in waste using location services like GPS or pin codes. The program takes in the location of the user and matches it to the nearest waste disposal place allocated before-hand in the database of the system.

The program requires the corporation to set up at least one waste disposal location in every pin code. The citizens can add further locations in detail if they wish to volunteer.

The proposed system matches the location information of the user with the location information in the database and informs the closest waste disposal location to the user. Further location information can also be added to the database by citizens who wish to volunteer to take in waste. This system increases the number of waste disposal locations in an area, which increases the convenience of waste disposal, as the user need not travel too far if there is a volunteer host nearby. The volunteers then can later transfer their collection of waste to the corporation.

The mobile based application also has the feature to snap pictures and send it to the required authorities. For example, a photo of waste littered on public roads can be sent to the corporation with the location information, hence letting them know where to clean up and take preventive measures. A photo of a person can also be sent to the nearby police station or the NGO or the social media through our application. Also there are feedback options provided in the application. Feedback can be provided to the NGO's in case the corporation fails to do its obligatory work.

The system at its fullest mainly focuses on simplifying the process of waste disposal by providing closer locations for waste disposal. By allowing the public to take part in the process as volunteers, two things are achieved, firstly, there will be much more increased locations for waste disposal and secondly, it will be a practical opportunity for the citizens to take part in cleaning their city which will lead them to a cleaner country. 


\section{IV.CONCLUSION}

The proposed "WASTEDISPO: AN ENHANCED APPROACH FOR WASTE DISPOSAL" which is very useful application mainly for inhabitants of cities. When we feel that there is need of waste management, for example when people throw garbage in public places such as railway stations, bus stands, crowded places (Shopping Mall, Temple, Colleges and many more.), foot paths, end of the street or road etc. we can use this application. On one click we can send our location to everyone and to nearby municipal office so if we have to dispose our garbage it will give us nearest location to dispose it and it will also provide volunteer ship to the individuals who are interested for that. The proposed system is more advanced and smart application in all context for Waste Management providing various features such as automated email, SMS, providing location using LBS (In absence of internet via local database)/GPS. More functionality will be provided such as automatic police and social help and SMS between apps and also maintaining local database and cloud database of user location.

\section{REFERENCES}

[1] Central pollution control board of India and Centre for science and environment as on February 2015.

[2] Hindustan Times (Lucknow): 2016-02-07

[3] Associated Chambers of Commerce and Industry (ASSOCHAM)

[4] www.litteritcostsyou.org

[5] Status of Municipal Solid Waste: Generation Collection Treatment and Disposal in Class I cities, CPCB April 2000.

[6] Manual on Municipal Solid Waste Management (first edition). Prepared by The Expert Committee constituted by the Ministry of Urban Development, The Government of India. January 2000

[7] Urban Waste: Status, trends and interventions. Ravi Agarwal, Srishti, January 2001.

[8] Personal Communication with Dr AK Tripathy, Ministry of Nonconventional Sources. 